Saudi Journal of Oral and Dental Research

Abbreviated Key Title: Saudi J Oral Dent Res

ISSN 2518-1300 (Print) |ISSN 2518-1297 (Online)

Scholars Middle East Publishers, Dubai, United Arab Emirates

Journal homepage: https://saudijournals.com/sjodr

\title{
"PEEK" - ING into the Future! A Literature Review on Use of PEEK polymer in Prosthodontics
}

\author{
Neda Essa M. Al Omar ${ }^{1}$, Khalil Ibrahim A. Idris ${ }^{2}$, Halah Athman A. Alaqi ${ }^{2}$, Ahmed Yahya A. Juraybi ${ }^{3}$, Saurabh Jain ${ }^{4 *}$ \\ ${ }^{1}$ General Dentist (The Ministry of Health), Jazan, KSA \\ ${ }^{2}$ General Dentist (Private Clinic), Jazan, KSA \\ ${ }^{3}$ General Dentist (The Ministry of Health), Albaha, KSA \\ ${ }^{4}$ Assistant Professor, Department of Prosthetic Dental Science, College of Dentistry, Jazan University, Jazan, KSA
}

DOI: $10.36348 /$ sjodr.2021.v06i01.005

| Received: 24.12.2020 | Accepted: 04.01.2021 | Published: 09.01.2021

*Corresponding author: Saurabh Jain

\section{Abstract}

Advances in material science and technologies has helped dentist in proving the best possible treatment options to the patients. Due to its superior Physical and mechanical properties, Polyetheretherketone (PEEK) has been tried in various aspects of dentistry. The use of PEEK in prosthodontics ranges from crowns, removable partial dentures, fixed partial denture and maxillofacial prosthesis and implant superstructures. The aim of this study is to review and evaluate the use of PEEK polymer in the field of Prosthodontics. The indexed English literature published was systematically searched for studies on PEEK and its use in prosthodontics. Full text of all the articles were studied to select final articles for this review. Suitable mechanical properties and biocompatibility is making PEEK a favorable material for use in prosthodontics. Further long-term In vivo studies are required, for this material to replace other conventional materials, used in prosthodontics.

Keywords: PEEK, Polyetheretherketone, Metal-free RPD, CAD/CAM prostheses.

Copyright (C) 2021 The Author(s): This is an open-access article distributed under the terms of the Creative Commons Attribution 4.0 International License (CC BY-NC 4.0) which permits unrestricted use, distribution, and reproduction in any medium for non-commercial use provided the original author and source are credited.

\section{INTRODUCTION}

Advances in material science and technologies has helped dentist in proving the best possible treatment options to the patients. For any new dental material to be used successfully in advanced dentistry, it should fulfill the basic minimal requirements. These requirements include biocompatibility, plaque repulsion, esthetic acceptability, and physical properties similar to natural oral and dental structures. Polyetheretherketone (PEEK) (-C6H4-OC6H4-OC6H4-CO-)n is a semi crystalline polycyclic aromatic polymer which was developed in late ninety's. PEEK was used as a substitute for metal implants for vertebral surgery [1-3]. Later with advancement in material science, carbon fiber reinforced PEEK material was used prosthetic material in artificial hip joints [4]. PEEK is under trial in various aspects of clinical dentistry. Due to its unique physical and mechanical properties, PEEK is a promising material for dental applications especially in prosthodontics. The use of
PEEK in prosthodontics ranges from crowns, removable partial dentures, fixed partial denture and maxillofacial prosthesis and implant superstructures [59]. The aim of this study is to review and evaluate the use of PEEK polymer in the field of Prosthodontics.

\section{MATERIALS AND METHODS}

The indexed English literature published up to $30^{\text {th }}$ November 2020, was systematically searched for studies on PEEK and its use in prosthodontics. Databases searched were PubMed, the Cochrane Library, and MEDLINE (OVID). Two reviewers independently screened and shortlisted the relevant studies based on predefined inclusion and exclusion criteria detailed in Table 1. Key terms were used while searching articles. Reference lists of relevant articles were manually searched to search more relevant articles. Full text of all the articles were studied to select final articles for this review. 
Neda Essa M. Al Omar et al; Saudi J Oral Dent Res, Jan 2021; 6(1): 29-33

Table-1: Inclusion and Exclusion Criteria

\begin{tabular}{|l|l|}
\hline Inclusion criteria & Exclusion criteria \\
\hline Literature in English language & Animal studies \\
\hline Human clinical studies & Literature in language other than English \\
\hline In vitro studies & Articles not related to use of peek in Prosthodontics \\
\hline Comparison between PEEK and different materials & Letters to the editor \\
\hline & Unpublished abstracts, reports, commentaries, Company literatures \\
\hline
\end{tabular}

\section{RESULTS}

398 articles were collected after initial search. Number of articles left after removing duplicates were 181. After reviewing titles and abstracts 37 articles were eligible for this study (Figure-1). These articles were read in details and relevant information was documented.
Table-2 describes the Division of studies on use of PEEK in dentistry. Out of total 93 studies, 37 $(39.8 \%)$ are on use of PEEK in prosthodontics, 29 $(31.2 \%)$ are on use of PEEK in implant dentistry, 10 $(10.8 \%)$ are on use of PEEK in other dental specialties, while $17(18.3 \%)$ studies discuss Physical and mechanical properties of PEEK.
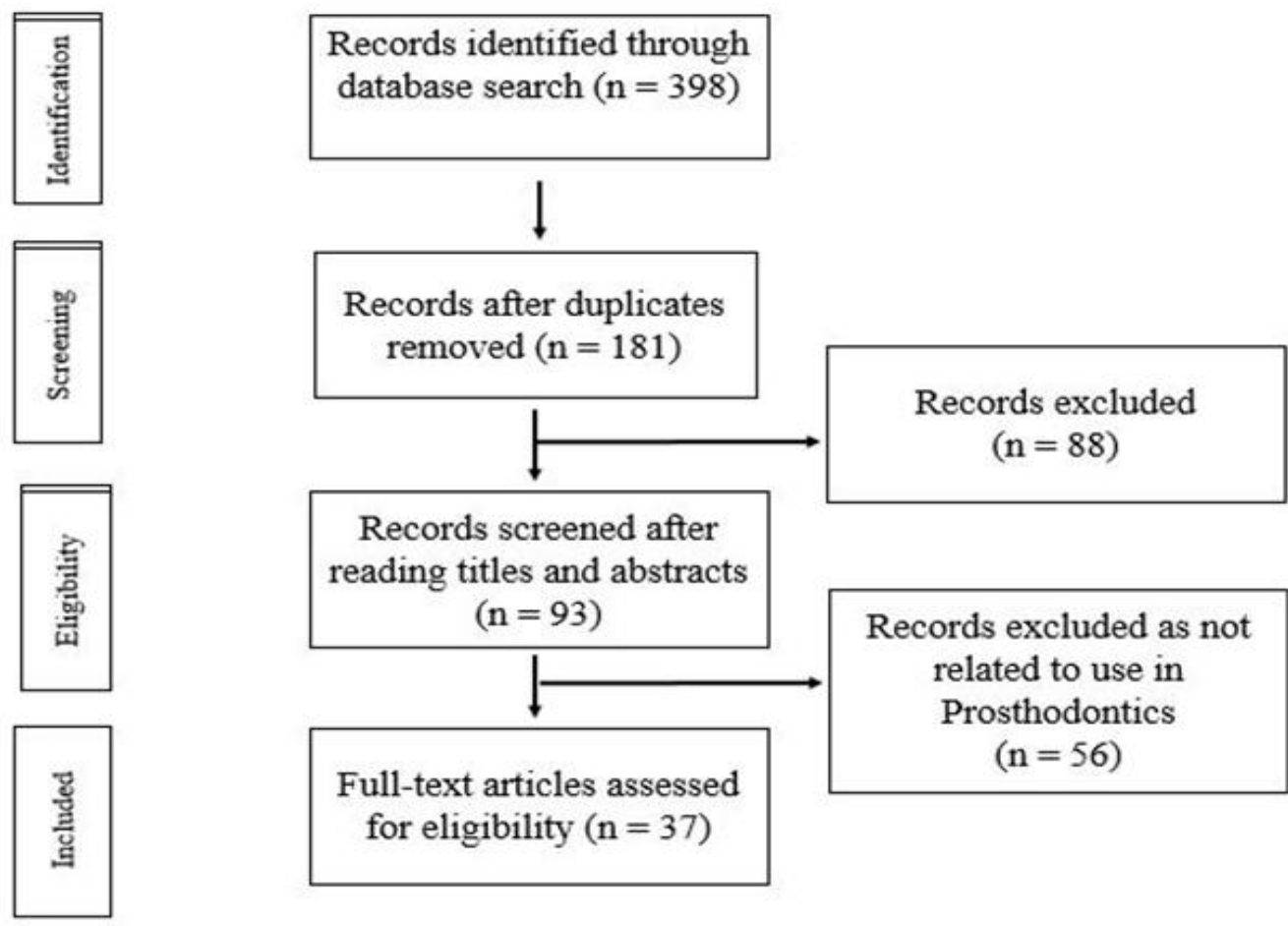

for eligibility $(\mathrm{n}=37)$

Fig-1: Article Selection Strategy

Table-2: Division of studies on use of PEEK in dentistry

\begin{tabular}{|l|l|l|}
\hline S. No & Division of studies on use of PEEK in dentistry & Total Number of articles (N=93) \\
\hline A) & Use of PEEK in Prosthodontics & $37(39.8 \%)$ \\
\hline & (i) Removable Partial Dentures (RPD) & $7(18.9 \%)$ \\
\hline & (ii) Fixed Partial Dentures (FPD) & $6(16.2 \%)$ \\
\hline & (iii) Crowns & $20(54.1 \%)$ \\
\hline & (iv) Maxillofacial Prosthesis & $4(10.8 \%)$ \\
\hline B) & PEEK in implant dentistry & $29(31.2 \%)$ \\
\hline D) & Physical and mechanical properties of PEEK & $17(18.3 \%)$ \\
\hline
\end{tabular}

\section{DISCUSSION}

\section{PEEK Polymer as RPD Framework}

Due to superior mechanical properties, PEEK is commonly used for fabricating removable partial denture (RPD) framework. Computer aided designing and computer aided manufacturing (CAD-CAM) can be used for this accurate fabrication of RPD frameworks [5]. Various studies reported that PEEK containing fillers (20\% ceramic fillers) (BioHPP) have improved physical properties and can be used successfully for 
Neda Essa M. Al Omar et al; Saudi J Oral Dent Res, Jan 2021; 6(1): 29-33

fabricating RPD frameworks [6, 10, 11]. PEEK is Lighter in weight, more aesthetic and causes less torquing forces on abutment tooth. Zoidis P et al., [12] \& Tannous F et al., [13] reported that the RPD direct retainers made of PEEK have a lower retentive force compared to those made from $\mathrm{Co}-\mathrm{Cr}$.

\section{PEEK as crown and FPD}

PEEK reinforced with other inorganic fillers is use for fabricating both provisional and definitive crowns and fixed partial dentures (FPDs) [7, 14]. Studies reported High fracture resistance [15], high patient comfort and acceptability and better marginal fit $[16,17]$ of CAD/CAM provisional crowns and FPDs made up of PEEK. Studies by Stawarczyk B et al., [18] and Skirbutis G et al., [19], reported that due to its grayish color, PEEK is not suitable for monolithic aesthetic restorations of anterior teeth. Veneering by composite should be done to achieve better esthetic results.

\section{PEEK as Obturator}

PEEK polymer has some of the properties which are highly desirable for any material to be used for fabricating Obturator prosthesis. One of the most important properties is weight. Many techniques are documented in the literature to make Obturator prosthesis (made from Poly methyl Methacrylate) lighter in weight [20]. Whereas, prosthesis made from PEEK are very light as compared to other material [21].
Weightlessness along with biocompatibility and ease of polishing will make PEEK polymer as material of choice in near future.

\section{PEEK as intraradicular post-core material}

PEEK has been tried as intraradicular postcore material. Lee et al., in their study found that post made from PEEK have high fracture resistance as compared to other commonly used post and core materials and there are less chances of root fracture when using PEEK [8].

\section{PEEK as superstructure for implants}

Studies by Adler et al., showed that Fatigue strength for BioHPP is very high and can be used as super structure for implants [9]. Thus PEEK can be used as superstructure for implants retained prosthesis.

\section{PEEK as dental implant material}

There is no common consensus in the literature with respect to osseointegrating properties of unmodified PEEK, when compared to conventional implant materials such as zirconia and titanium. Few studies suggest that there is no significant difference [22], while others suggest that osseointegration is poorer than conventional implant materials [23, 24]. Various methods (Surface treatment, Coating and Bio composite) are suggested in the literature to improve the osseointegration of PEEK polymer [25].

Table-3: Use of PEEK in Prosthodontics: Advantages, Disadvantages and Limitations

\begin{tabular}{|c|c|c|c|}
\hline $\begin{array}{l}\text { Use of PEEK in } \\
\text { Prosthodontics }\end{array}$ & Advantages & Disadvantages & Limitations \\
\hline $\begin{array}{l}\text { As RPD framework } \\
\text { Peek containing fillers } \\
\text { (20\% ceramic fillers) } \\
\text { (BioHPP) }\end{array}$ & $\begin{array}{ll}\text { - } & \text { Lighter weight } \\
\text { - } & \text { Aesthetic } \\
\text { - } & \text { Less torquing forces on } \\
& \text { abutment tooth } \\
\end{array}$ & $\begin{array}{l}\text { PEEK direct retainers have lower } \\
\text { retentive force compared to } \mathrm{Co}-\mathrm{Cr} \\
\text { retainers }\end{array}$ & $\begin{array}{l}\text { Paucity of long- } \\
\text { term In vivo } \\
\text { studies }\end{array}$ \\
\hline $\begin{array}{l}\text { As crown and } \boldsymbol{F P D} \\
\text { PEEK reinforced with } \\
\text { other inorganic fillers }\end{array}$ & $\begin{array}{ll}- & \text { High fracture resistance } \\
\text { - } & \text { High patient comfort and } \\
\text { acceptability } \\
\text { - } & \text { Better marginal fit of } \\
\text { provisional crowns } \\
\end{array}$ & $\begin{array}{l}\text { Grayish brown color. Should be } \\
\text { layered with composite to achieve } \\
\text { aesthetic results. }\end{array}$ & $\begin{array}{l}\text { Paucity of long- } \\
\text { term In vivo } \\
\text { studies }\end{array}$ \\
\hline As Obturator & $\begin{array}{ll}\text { - } & \text { Lighter weight } \\
\text { - } & \text { Biocompatibility } \\
\text { - } & \text { Ease of polishing } \\
\end{array}$ & - & $\begin{array}{l}\text { Paucity of long- } \\
\text { term In vivo } \\
\text { studies }\end{array}$ \\
\hline $\begin{array}{l}\text { As intraradicular post- } \\
\text { core material }\end{array}$ & $\begin{array}{ll}\text { - } & \text { High fracture resistance } \\
\text { - } & \text { Less chances of root } \\
\text { fracture }\end{array}$ & - & $\begin{array}{l}\text { Paucity of long- } \\
\text { term In vivo } \\
\text { studies }\end{array}$ \\
\hline $\begin{array}{l}\text { As superstructure for } \\
\text { implants } \\
\text { BioHPP appears to be } \\
\text { appropriate for implant } \\
\text { superstructures } \\
\end{array}$ & $\begin{array}{l}\text { High Fatigue strength } \\
(1200 \mathrm{~N})\end{array}$ & 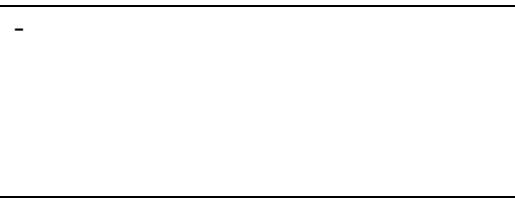 & $\begin{array}{l}\text { Paucity of long- } \\
\text { term In vivo } \\
\text { studies }\end{array}$ \\
\hline $\begin{array}{l}\text { As dental implant } \\
\text { material }\end{array}$ & \multicolumn{2}{|c|}{$\begin{array}{l}\text { No common consensus in the literature with respect to osseointegrating } \\
\text { properties of PEEK when compared to conventional implant materials } \\
\text { such as zirconia and titanium. }\end{array}$} & $\begin{array}{l}\text { Paucity of long- } \\
\text { term In vivo } \\
\text { studies }\end{array}$ \\
\hline
\end{tabular}




\section{CONCLUSION}

The current article reviews the use of PEEK in prosthodontics. Suitable mechanical properties and biocompatibility is making PEEK a favorable material for use in prosthodontics. Further long-term In vivo studies are required, for this material to replace other conventional materials, used in prosthodontics.

\section{REFERENCES}

1. Toth, J. M., Wang, M., Estes, B. T., Scifert, J. L., Seim, H. B., 3rd, \& Turner, A. S. (2006). Polyetheretherketone as a biomaterial for spinal applications. Biomaterials, 27(3), 324-334. https://doi.org/10.1016/j.biomaterials.2005.07.011

2. Kurtz, S. M., \& Devine, J. N. (2007). PEEK biomaterials in trauma, orthopedic, and spinal implants. Biomaterials, 28(32), 4845-4869. https://doi.org/10.1016/j.biomaterials.2007.07.013

3. Pokorný, D., Fulín, P., Slouf, M., Jahoda, D., Landor, I., \& Sosna, A. (2010). Polyetheretherketon (PEEK)--II. část: Poznatky o využití v klinické praxi [Polyetheretherketone (PEEK). Part II: application in clinical practice]. Acta chirurgiae orthopaedicae et traumatologiae Cechoslovaca, 77(6), 470-478.

4. Ma, R., \& Tang, T. (2014). Current strategies to improve the bioactivity of PEEK. International journal of molecular sciences, 15(4), 5426-5445. https://doi.org/10.3390/ijms15045426

5. Harb, I. E., Abdel-Khalek, E. A., \& Hegazy, S. A. (2019). CAD/CAM Constructed Poly (etheretherketone) (PEEK) Framework of Kennedy Class I Removable Partial Denture: A Clinical Report. Journal of prosthodontics: official journal of the American College of Prosthodontists, 28(2),

https://doi.org/10.1111/jopr.12968

6. Seferis, J. C. (1986). Polyetheretherketone (PEEK): Processing-structure and properties studies for a matrix in high performance composites. Polymer Composites, 7(3),158-169.

7. Zhou, L., Qian, Y., Zhu, Y., Liu, H., Gan, K., \& Guo, J. (2014). The effect of different surface treatments on the bond strength of PEEK composite materials. Dental materials: official publication of the Academy of Dental Materials, 30(8), $\quad$ e209-e215. https://doi.org/10.1016/j.dental.2014.03.011

8. Lee, K. S., Shin, J. H., Kim, J. E., Kim, J. H., Lee, W. C., Shin, S. W., \& Lee, J. Y. (2017). Corrigendum to "Biomechanical Evaluation of a Tooth Restored with High Performance Polymer PEKK Post-Core System: A 3D Finite Element Analysis". BioMed research international, 2017, 7196847. https://doi.org/10.1155/2017/7196847

9. Bathala, L., Majeti, V., Rachuri, N., Singh, N., Gedela, S. (2019). The Role of Polyether Ether Ketone (Peek) in Dentistry - A Review. Journal of Medicine and Life, 12(1):5-9.
10. Katzer, A., Marquardt, H., Westendorf, J., Wening, J. V., \& von Foerster, G. (2002). Polyetheretherketone--cytotoxicity and mutagenicity in vitro. Biomaterials, 23(8), 1749 $1759 . \quad$ https://doi.org/10.1016/s01429612(01)00300-3

11. Rivard, C. H., Rhalmi, S., \& Coillard, C. (2002). In vivo biocompatibility testing of peek polymer for a spinal implant system: a study in rabbits. Journal of biomedical materials research, 62(4), 488-498. https://doi.org/10.1002/jbm.10159

12. Zoidis, P., Papathanasiou, I., \& Polyzois, G. (2016). The Use of a Modified Poly-Ether-EtherKetone (PEEK) as an Alternative Framework Material for Removable Dental Prostheses. A Clinical Report. Journal of prosthodontics: official journal of the American College of Prosthodontists, 25(7), $580-584$. https://doi.org/10.1111/jopr.12325

13. Tannous, F., Steiner, M., Shahin, R., \& Kern, M. (2012). Retentive forces and fatigue resistance of thermoplastic resin clasps. Dental materials: official publication of the Academy of Dental Materials, 28(3), 273-278. https://doi.org/10.1016/j.dental.2011.10.016

14. Schmidlin, P. R., Stawarczyk, B., Wieland, M., Attin, T., Hämmerle, C. H., \& Fischer, J. (2010). Effect of different surface pre-treatments and luting materials on shear bond strength to PEEK. Dental materials : official publication of the Academy of Dental Materials, 26(6), 553-559. https://doi.org/10.1016/j.dental.2010.02.003

15. Stawarczyk, B., Eichberger, M., Uhrenbacher, J., Wimmer, T., Edelhoff, D., \& Schmidlin, P. R. (2015). Three-unit reinforced polyetheretherketone composite FDPs: influence of fabrication method on load-bearing capacity and failure types. Dental materials journal,34(1), 7-12. https://doi.org/10.4012/dmj.2013-345

16. Abdullah, A. O., Tsitrou, E. A., \& Pollington, S. (2016). Comparative in vitro evaluation of $\mathrm{CAD} / \mathrm{CAM}$ vs conventional provisional crowns. Journal of applied oral science : revista FOB , 24(3), https://doi.org/10.1590/1678-775720150451

17. Sinha, N., Gupta, N., Reddy, K. M., \& Shastry, Y. M. (2017). Versatility of PEEK as a fixed partial denture framework. Journal of Indian Prosthodontic Society, 17(1), 80-83. https://doi.org/10.4103/0972-4052.197941

18. Stawarczyk, B., Beuer, F., Wimmer, T., Jahn, D., Sener, B., Roos, M., \& Schmidlin, P. R. (2013). Polyetheretherketone-a suitable material for fixed dental prostheses?.Journal of biomedical materials research. Part B, Applied biomaterials, 101(7), 1209-1216. https://doi.org/10.1002/jbm.b.32932

19. Skirbutis, G., Dzingutè, A., Masiliūnaite, V., Šulcaite, G., \& Žilinskas, J. (2017). A review of 
PEEK polymer's properties and its use in prosthodontics. Stomatologija, 19(1), 19-23.

20. Jain, S., Aggarwal, A., Shetty, S. (2014). An innovative technique for fabrication of a hollow maxillary resection prosthesis: A Case Report. Indian J Dent Sci, 6(5), 55-57.

21. Costa-Palau, S., Torrents-Nicolas, J., Brufau-de Barberà, M., \& Cabratosa-Termes, J. (2014). Use of polyetheretherketone in the fabrication of a maxillary obturator prosthesis: a clinical report. The Journal of prosthetic dentistry, 112(3), 680-682.

https://doi.org/10.1016/j.prosdent.2013.10.026

22. Sagomonyants, K. B., Jarman-Smith, M. L., Devine, J. N., Aronow, M. S., \& Gronowicz, G. A. (2008). The in vitro response of human osteoblasts to polyetheretherketone (PEEK) substrates compared to commercially pure titanium. Biomaterials, 29(11), 1563-1572. https://doi.org/10.1016/j.biomaterials.2007.12.001
23. Najeeb, S., Bds, Z. K., Bds, S. Z., \& Bds, M. S. (2016). Bioactivity and Osseointegration of PEEK Are Inferior to Those of Titanium: A Systematic Review. The Journal of oral implantology, 42(6), 512-516. https://doi.org/10.1563/aaid-joi-D-1600072

24. Olivares-Navarrete, R., Gittens, R. A., Schneider, J. M., Hyzy, S. L., Haithcock, D. A., Ullrich, P. F., Schwartz, Z., \& Boyan, B. D. (2012). Osteoblasts exhibit a more differentiated phenotype and increased bone morphogenetic protein production on titanium alloy substrates than on poly-etherether-ketone. The spine journal: official journal of the North American Spine Society, 12(3), 265-272. https://doi.org/10.1016/j.spinee.2012.02.002

25. AlOtaibi, N., Naudi, K., Conway, D., \& Ayoub, A. (2020). The current state of PEEK implant osseointegration and future perspectives: a systematic review. European cells \& materials, 40, 1-20. https://doi.org/10.22203/eCM.v040a01. 